\title{
Long term effect of applied compost and bio-agents as integrated treatment for controlling bean root rot disease in solarized soil under field conditions
}

\section{El-Mougy NS, Abdel-Kareem F, Abdel-Kader MM* and Fatouh YO}

Plant Pathology Dept., National Research Centre, Dokki 12622, Giza, Egypt

El-Mougy NS, Abdel-Kareem F, Abdel-Kader MM, Fatouh YO 2013 - Long term effect of applied compost and bio-agents as integrated treatment for controlling bean root rot disease in solarized soil under field conditions. Plant Pathology \& Quarantine 3(1), 41-52, doi 10.5943/ppq/3/1/7

Management of Bean (Phaseolus vulgarus L.) root rot disease caused by Fusarium solani and Rhizoctonia solani was investigated. Efficacy of $T$. harzianum and $P$. fluorescens alone or in combination with compost for controlling bean root rot disease in solarized or un-solarized soil under field conditions were studied. In vitro the highest reduction was obtained with $P$. fluorescens and $T$. harzianum which reduced the growth area more than 90.6 and $87.4 \%$ for $F$. solani and $R$. solani respectively. Under field conditions, the average maximum of soil temperatures in solarized soil was increased by $15.0,14.3$ and $13.1^{\circ} \mathrm{C}$ at depths of 10,20 and $30 \mathrm{~cm}$ of soil surface as compared with un-solarized soil. The pronounced applied treatments throughout two successive growing seasons were compost A (animal waste) combined with T. harzianum or P. fluorescens, followed by compost $\mathrm{P}$ (agriculture waste) combined with the same bioagents in solarized soil which they reduced the root rot disease at pre-, and post-emergence growth stages, respectively. As for bean yield the highest increase was obtained at combined treatments of compost A and $T$. harzianum or $P$. fluorescens, followed by combined treatments between compost $\mathrm{P}$ and $T$. harzianum or P. fluorescens in solarized soil. Referring to the obtained results in the present study, it could be suggested that combined treatment between compost and bioagents as safety method might be used commercially for controlling bean root rot disease under field conditions.

Key words - Bean - Bio-agents - Compost - Disease control - Root rot

Article Information

Received 11 May 2013

Accepted 3 June 2013

Published online 25 June 2013

*Corresponding author: Mokhtar Abdel-Kader - email - mokh_nrc@yahoo.com

\section{Introduction}

Bean plants (Phaseolus vulgarus L.) is one of the most important leguminous crops in Egypt. Root rot disease caused by Fusarium solani and Rhizoctonia solani is a serious and persistent disease problem of bean plants during growing season (Filion et al. 2003; Harveson et al. 2005; Wen et al. 2005). Fungal disease control is achieved through the use of fungicides which is hazardous and toxic to both people and domestic animals and leads to environmental pollution. Therefore, a more 
balanced, cost effective and eco-friendly approach must be implemented and adopted farmers. In order to overcome such hazardous control strategies, scientists, researchers from all over the world paid more attention towards the development of alternative methods which are, by definition, safe in the environment, non-toxic to humans and animals and are rapidly biodegradable. There is a growing need to develop alternative approaches for controlling plant diseases. Such strategy is use of bio-control agents to control fungal plant diseases as well as other fungicides alternatives (Sivan 1987; Punja \& Utkhede 2004). Trichoderma spp. are effective bio-control agents for a number of soil-borne plant pathogens, and also known for their ability to enhance plant growth (Sharon et al. 2001; Rose et al. 2003). Recently, it was suggested that Trichoderma affects induced systemic resistance (ISR) mechanism in plants (Shoresh et al. 2005; Horst et al. 2005; Hoitink et al. 2006).

On the other hand, the incidence of several soil-borne plant pathogens have also been reduced by using composts made of different raw materials (Hoitink \& Fahy 1986; Hoitink \& Boehm 1999; Cotxarrera et al. 2002; Borrero et al. 2004). Since Hoitink et al. (1975) first suggested compost could be used as a peat substitute to control root pathogens, biocontrol research has increasingly focused on developing the right combination of composts and antagonistic microbes. Trichoderma in combination with composts from agricultural wastes, was used to suppress Rhizoctonia solani in cucumber seedlings (Trillas et al. 2006), and Trichoderma sp. and sewage sludge compost were used to suppress Fusarium wilt of tomato (Cotxarrera et al. 2002). Currently it is believed that a combination of antagonistic microbes with mature compost may be more efficient in inhibiting disease than using single antagonistic microbial strains or compost alone (Sivan \& Chet 1992; Cotxarrera et al. 2002; Trillas et al. 2006). Soil mulching was carried out as physical disease control methods using transparent polyethylene plastic placed on moist soil during the hot summer months increases soil temperatures to levels lethal to many of soil-borne plant pathogens, weeds and nematodes (Primo \& Cartia 2001; Abd-ElKareem et al. 2004; Culman et al. 2006; Farag $\&$ Fotouh 2010). The objective of the present work was designed to evaluate the effect of $T$. harzianum and $P$. fluorescens alone or in combination with compost against bean root rot disease in solarized or un-solarized soil under field conditions.

\section{Materials and Methods}

\section{Source of pathogenic fungi, bio-agents, bean seeds and compost}

Pathogenic fungal isolates of Rhizoctonia solani (AG 4) and Fusarium solani as the causal agents of bean root rot disease were isolated from diseases bean plants grown previously from the field study located at the Experimental Research Station of National Research Centre at El-Noubaria region, Behera Governorate, Egypt.

The bio-agents, Trichoderma

harzianum and Pseudomonas fluorescens were kindly obtained from culture collection unit of Plant Pathology Dept., National Research Centre, Giza, Egypt. These isolates proved their high antagonistic effect against several soil-borne plant pathogens causing root rot and wilt diseases to various vegetables and field crops in previous works at the same Department.

Bean seeds cv. Giza 3 were obtained from Vegetable Crops Research Dept., Agricultural Research Centre, Giza, Egypt. Commercial Compost A (made from animal waste) and compost $\mathrm{P}$ (made from agriculture waste) were purchased from Egyptian Company for Solid Waste Utilization (ECARU), Giza, Egypt, were used in field trails. Characteristics of the tested composts are shown in Table (1) as analyzed according to Page et al (1982) as follows: Compost samples were air-dried and sieved through a 2$\mathrm{mm}$ mesh prior to analysis. The compost $\mathrm{pH}$ was po-tentiometrically determined in a 1:1 compost:water ratio (Mclean 1982). The compost organic carbon was determined using the Walkey-Black method (Nelson and Sommers 1982), and the total nitrogen of the 
Table 1 Characterization of used composts

\begin{tabular}{lcc}
\hline \multicolumn{1}{c}{$\begin{array}{c}\text { Compost } \\
\text { characteristics }\end{array}$} & $\begin{array}{c}\text { Value } \\
\text { Compost P } \\
\text { (made from } \\
\text { agriculture } \\
\text { waste) }\end{array}$ & $\begin{array}{c}\text { Compost A } \\
\text { (made from } \\
\text { animal waste) }\end{array}$ \\
\hline PH & 6.19 & 6.59 \\
Electrical conductivity & 3.01 & 3.12 \\
(E.C \%) & & \\
C/N ratio & 11.42 & 13.27 \\
Organic matter (O.M) \% & 34.55 & 48.64 \\
Nitrogen (N \%) & 3.26 & 6.82 \\
Phosphorus (P \%) & 0.78 & 1.34 \\
Potassium (K \%) & 2.18 & 3.46 \\
\hline
\end{tabular}

compost was determined using the macroKjeldahl method (Bremner and Mulvaney 1982). The available phosphorus in the compost was determined using the Bray P1 method (Olsen and Sommers 1982), and the $\mathrm{K}+$ were determined using $1 \mathrm{M} \mathrm{\textrm {NH } _ { 4 } \mathrm { OAc }}$ (ammonium acetate) buffered at $\mathrm{pH} 7.0$ as the extractant (Thomas 1982). The exchangeable conductivity (EC) in the compost was extracted with $1 \mathrm{M} \mathrm{KCl}$ (Thomas 1982), and the extract was titrated with $0.05 \mathrm{M} \mathrm{NaOH}$ using phenolphthalein as the indicator (Odu et al. 1986).

\section{Laboratory tests}

Evaluation of the antagonistic effect of bio-agents on the growth of bean root-rot fungi was carried out in vitro. Two bio-agents, $T$. harzianum and $P$. fluorescens were tested for their antagonistic effect against the growth of pathogenic fungi, $R$. solani and $F$. solani under in vitro conditions following the methods described by Ferreira et al. (1991). The antagonistic isolates of $T$. harzianum and $P$. fluorescens, were obtained from the Plant Pathology Department of the National Research Centre, Giza, Egypt. These microorganisms were isolated from the rhizosphere of various healthy and root rot infected leguminous crops, grown in the Delta and Middle Egypt regions, and proved their high antagonistic ability during previous work at the same department. Cultures of pathogenic and antagonistic fungi grown on PDA medium for 10 days as well as bacterial cultures which grown on nutrient broth for 2 days were used in this test. Mycelial disks (6 mm diameter) of pathogenic fungi, $F$. solani and $R$. solani were transferred singly to the center of Petri plates ( $9 \mathrm{~cm}$ diameter) containing PDA medium. Four loop growth of each antagonistic bacterium from 2-days old grown on nutrient broth cultures were placed at four corners of the plate in perpendicular positions. Disks of either T. harzianum or each pathogenic fungi growth were placed on opposite sides of Petri plates containing PDA medium. Inoculated plates were incubated for 7 days at $23^{\circ} \mathrm{C}$. Five plates for each particular treatment were used as replicates. Growth area reduction was calculated for the pathogenic fungi using the following equation:

Growth reduction $\%=$

Growth area in control-growth area in treatment $\times 100$ Growth area in control

Whereas: Growth area $=\left(\pi \times r^{2}\right)$

\section{Field experiments}

The field experiment carried out at the Experimental Research Station of National Research Centre at El-Noubaria region, Behera Governorate, Egypt. Under field conditions, the efficacy of bio-agents, $T$. harzianum and $P$. fluorescens alone or in combination with composts (compost $\mathrm{P}$ made from agriculture waste and compost A from animal waste) applied in solarized and un-solarized soil was 
Table 2 Growth area of bean root rot pathogenic fungi affected with some bio-agents in Vitro

\begin{tabular}{|c|c|c|c|c|}
\hline \multirow[b]{3}{*}{ Bio-agent } & \multicolumn{4}{|c|}{ Bean root rot pathogenic fungi } \\
\hline & & olani & & solani \\
\hline & $\begin{array}{c}\text { Growth } \\
\text { area } \\
\left(\mathrm{cm}^{2}\right)\end{array}$ & $\underset{\%}{\text { Reduction }}$ & $\begin{array}{c}\text { Growth } \\
\text { area } \\
\left(\mathrm{cm}^{2}\right)\end{array}$ & $\underset{\%}{\text { Reduction }}$ \\
\hline P. fluorescens & 5.4 & 91.5 & 6.0 & 90.6 \\
\hline T. harzianum & 7.0 & 89.0 & 8.0 & 87.4 \\
\hline Control & 63.6 & - & 63.6 & - \\
\hline LSD at 0.05 & 19.68 & - & 22.33 & - \\
\hline
\end{tabular}

studied against bean root rot disease during two growing seasons. The field trail conducted in 60 plots, each $12 \mathrm{~m}^{2}$ ( $3 \mathrm{~m}$ width $\mathrm{x} 4 \mathrm{~m}$ length) comprised of 5 rows with $4 \mathrm{~m}$ length and 20 holes/row, established in naturally heavily infested soil with root rot pathogens $R$. solani and $F$. solani. All plots were irrigated to field capacity and 30 plots were subjected to solarization treatment which carried out by covering with $100 \mu \mathrm{m}$ thick transparent polyethylene sheets for 8 weeks during JulyAugust 2011, then removed. Maximum and minimum degrees of soil temperature were regularly measured during that period at the soil depths of 10,20 and $30 \mathrm{~cm}$. The average temperature at the three soil depths was calculated at the end of mulching period. The other untreated 30 plots were considered as un solarized one.

After removing the polyethylene sheets the following treatments were applied either in solarized or un-solarized soil:

(A) Single treatments

1- Compost $p$

2- Compost A

3- T. harzianum

4- P. fluorescens

(B) Combined treatments

5- Compost $\mathrm{p}+T$. harzianum

6- Compost $\mathrm{p}+P$. fluorescens

7- Compost $\mathrm{A}+T$. harzianum

8- Compost $\mathrm{A}+P$. fluorescens

9- Fungicide (Rizolex-T 50\% at the rate of $3 \mathrm{~g} / \mathrm{Kg}$ seeds as seed dressing)

10- Untreated control (general control for single and combined treatments)

The antagonistic fungal inoculum $T$. harzianum was grown on PDA medium at
$28 \pm 1^{\circ} \mathrm{C}$ until an abundant heavy growth of conidia was evident. Conidia were harvested by scraping the surface of the colonies with a spatula, transferred to sterilized distilled water and filtered through nylon mesh to avoid the mycelium fragments. Spore solution was adjusted with sterile water to give a spore concentration of $10^{6}$ spores per milliliter. Meanwhile, antagonistic bacteria $P$. fluorescence was grown on Nutrient broth medium and incubated in a rotary shaker at 200 rpm for $24 \mathrm{~h}$ at $28 \pm 1^{\circ} \mathrm{C}$. The bacterial cells were harvested by centrifugation at $6,000 \mathrm{rpm}$ for 10 min, washed twice with $0.05 \mathrm{M}$ phosphate buffer at $\mathrm{pH}$ 7.0, and re-suspended in distilled water. The concentrations of bacterial cells in the suspensions were adjusted to $10^{8}$ cells per milliliter. Concentrations of both bacterial cells and fungal spore suspensions were adjusted with the aid of a haemocytometer slide. The antagonistic bio-agents were individually mixed thoroughly at rate of $1.0 \%(\mathrm{v} / \mathrm{w})$ with composts $\mathrm{A}$ and $\mathrm{P}$ individually before soil application. All Compost treatments were applied at rate of 20 $\mathrm{m}^{3}$ /feddan $\left(4200 \mathrm{~m}^{2}\right)$. Compost and/or Bioagents inocula were incorporated in the top of $20 \mathrm{~cm}$ of the soil surface at planting row sites considering relevant treatments. The prepared solution of Bio-agents mixture was also individually incorporated into the same cultivated row site at the rate of $2 \mathrm{~L} / \mathrm{row}(4 \mathrm{~m})$ after Abdel-Kader (1997). All treatments were applied in Complete Randomized Block Design with three replicates (plots) for each particular treatment. The Bean seeds cv. Giza 3 were sown for two successive seasons (winter and early summer growing seasons September, 2011 and March, 2012) using the same field design plots for the purpose of evaluating the long term effect of applied treatments. Three bean seeds 
were sown per hole with $20 \mathrm{~cm}$ spaces between holes.

\section{Disease assessment}

Percentage of root rot incidence at the pre-emergence stage was calculated as the number of absent emerged seedlings in relative to the total number of sown seeds. Meanwhile, percentage of post- emergence root rot was calculated as the number of bean plants showing disease symptoms in relative to the total number of emerged seedlings. Undeveloped, germinated seeds as well as diseased plants were picked up from the soil, washed and sterilized with $3 \%$ sodium hypochlorite, then subjected to re-isolation trail in order to identify the causal pathogens. Plant roots showing rot lesions in addition to the visual root rot symptoms on the shoot system were considered diseased plants.

The percentages of pre-emergence root rot incidence was calculated after 20 days from sowing, meanwhile post-emergence bean root rot incidence was recorded periodically every 10 days starting from 20 up to 60 days of plant growth. Determination of accumulated bean yield per $\mathrm{m}^{2}$ was calculated. The average percentage of disease incidence and the obtained yield for the two successive growing seasons were calculated and presented.

\section{Statistical analysis}

All in vitro and in vivo experiments were set up in Completely Randomized Design (CRD). The data collected were analyzed using Michigan Statistical Program Version C (MS MSTAT-C program (MSTAT-C, 1988). The means differences were compared by Least Significant Difference test (LSD) value at 0.05 for comparison between means of treatments were used as mentioned by Snedecor and Cochran (1973).

\section{Results}

\section{Laboratory tests}

Evaluation the antagonistic effect of bio-agents on the growth of bean root-rot fungi was carried out in vitro. The antagonistic effect of T. harzianum and P. fluorescens against the linear growth of pathogenic fungi $F$. solani and $R$. solani was presented in Table (2). The obtained results indicate that both bio-agents significantly reduced the growth area of pathogenic fungi. The growth area of $R$. solani recorded as 5.4 and $7.0 \mathrm{~cm}^{2}$ when grown against the bio-agents $P$. fluorescens and $T$. harzianum, respectively. Meanwhile, $F$. solani growth area recorded as 6.0 and $8.0 \mathrm{~cm}^{2}$ when exposed to $P$. fluorescens and $T$. harzianum in the same growth medium. On the other hand, the growth area of both pathogenic fungi recorded $63.6 \mathrm{~cm}^{2}$ in growth medium free of bio-agents.

\section{Field experiments}

Isolation trails of undeveloped, germinated seeds as well as bean diseased plants revealed that the causal pathogens were $R$. solani (AG4) and $F$. solani. These fungi were identified according to Gilman (1957); Barnett and Hunter (1972).Hunter (1972). Under field conditions, average of maximum and minimum soil temperatures in solarized and un-solarized soil was recorded during solarization period. Results in Table (3) indicate that maximum soil temperatures in solarized soil was increased by $15.0,14.3$ and $13.1^{\circ} \mathrm{C}$ at depths of 10,20 and $30 \mathrm{~cm}$ of soil surface as compared with un-solarized soil. The highest increase in soil temperatures was obtained at solarized soil which recorded 56.5, 51.5 and $46.5^{\circ} \mathrm{C}$ as maximum soil temperatures at three depths, respectively. Disinfestation of soil of soilborne pathogens and pests has been mainly based on methods of soil fumigation and soil steaming (Baker and Cook 1974; Dawson et al. 1965). However, the report of Katan et al. (1976) in 1976 on the use of solar heating for disinfesting soil of pathogens and pests, now known as soil solarization, attracted the attention of many agriculturalists and is now widely used (Katan et al. 1987). Plant pathogenic fungi are among the most sensitive soilborne organisms to soil solarization, especially species that are unable to grow at temperatures higher than $30^{\circ}$ to $33^{\circ} \mathrm{C}$; they are categorized as mesophiles. Immediately after soil solarization, the population densities of "total" fungi were reduced by 85 to 90 percent 
Table 3 Averages of maximum and minimum soil temperatures at different soil depths in mulched and un-mulched soil during July and Augusts, 2011.

\begin{tabular}{ccccc}
\hline $\begin{array}{c}\text { Soil depth } \\
\text { (cm) }\end{array}$ & \multicolumn{2}{c}{ Mulched soil } & \multicolumn{2}{c}{ Un mulched soil } \\
Min. $^{\mathbf{}}{ }^{\mathbf{C}} \mathbf{C}$ & Max. $^{\mathbf{0}} \mathbf{C}$ & Min. $^{\mathbf{}} \mathbf{C}$ & Max. $^{\mathbf{0}} \mathbf{C}$ \\
\hline 10 & 40.2 & 56.5 & 25.0 & 41.5 \\
20 & 37.0 & 51.5 & 27.0 & 37.2 \\
30 & 35.0 & 46.5 & 23.0 & 33.4 \\
LSD at 0.05 & 1.82 & 3.64 & 2.14 & 3.27 \\
\hline
\end{tabular}

in different experimental plots. However, population densities of thermotolerant and thermophilic fungi remained relatively high following solarization, and increased to levels higher than present in non-solarized soil (Stapleton and DeVay 1982). Depending on soil depth, maximum temperatures of solarized soil in field areas are commonly between $42^{\circ}$ to $55^{\circ} \mathrm{C}$ at the $5 \mathrm{~cm}$ depth and range from $32^{\circ}$ to $36^{\circ} \mathrm{C}$ at the $45 \mathrm{~cm}$ depth. Solarized soil under glasshouse conditions or under double layers of transparent PE film, reaches higher temperatures than soil under a single layer of film in the field (Horiuchi 1984; Cenis 1987).

Applied field treatments of $T$. harzianum and $P$. fluorescens alone or in combination with compost in solarized or unsolarized soil were evaluated for their long term effect against bean root rot disease throughout two successive growing seasons (winter and early summer growing seasons). Presented results in Table (4) indicate that all treatments significantly reduced the disease incidence at two seasons. All applied treatments in solarized soil were effective against disease incidence than un-solarized soil. Data also showed that the most pronounced treatments, were the compost A plus $T$. harzianum or $P$. fluorescens in solarized soil which reduced the root rot disease by $73.3 \&$ 86.8 and $70.7 \& 85.3 \%$ at pre-, and postemergence growth stages, followed by combined treatments between compost $\mathrm{P}$ and $T$. harzianum or $P$. fluorescens in solarized soil which reduced the root rot disease more than 65.3 and $73.5 \%$ for pre-, and post-emergence, in respective order. Meanwhile, single treatments showed moderate effect. Similar trend was also observed in un-solarized soil.

As for bean yield the obtained results are presented data in Table (5). Data showed the influence of $T$. harzianum and $P$. fluorescens alone or in combination with compost on produced yield of bean plants grown in solarized or un- solarized soil. Applied treatments of $T$. harzianum and P. fluorescens alone or in combination with compost indicate significant increase of bean yield. Also, applied treatments in solarized soil were more effective in yield increase than un-solarized soil. The highest increase was obtained with combined treatments between compost A and $T$. harzianum or $P$. fluorescens in solarized soil which increased the bean yield by $66.0,60.0 \%$ and $64.4,56.3 \%$ at the two successive growing seasons, respectively. Similarly, combined treatments between compost $\mathrm{P}$ and $T$. harzianum or $P$. fluorescens in solarized soil increased the bean yield by $45.0,46.0 \%$ and $42.4,44.8 \%$ at the two successive growing seasons, in respective order. Meanwhile, single treatments applied in solarized soil showed moderate yield increase ranged between 20.0$34.5 \%$ and $18.6-32.5 \%$ at the two successive growing seasons, respectively. The similar trend was observed in un-solarized soil at all applied treatments. The similar trend was observed in un-solarized soil at all applied treatments.

\section{Discussion}

Root rot of faba bean caused by a complex of $F$. solani and $R$. solani is considered among the most deleterious diseases, causing great losses in many parts of the world (Celar 2000; Filion et al. 2003; Harveson et al. 2005; Wen et al. 2005). Biological control of plant diseases, especially soil-borne plant pathogens, has been the subject of much research in the last two decades. Therefore, biological control of plant pathogens is becoming an important 
component of plant disease management practices. In this regard, Trichoderma harzianum and $P$. fluorescens are reported to be effective bio-control agents for a number of soil-borne plant pathogens, and also known for their ability to enhance plant growth (Sharon et al. 2001; Rose et al. 2003). In present study results indicate that both bio-agents significantly reduced the growth area of pathogenic fungi under in vitro conditions. The highest reduction was obtained with $P$. fluorescens and T. harzianum which reduced the growth area by $91.5 \& 90.6$ and $89.0 \&$ $87.4 \%$ for $F$. solani and $R$. solani respectively. Such results concerning the inhibitory effect of various bacterial and fungal antagonists on soil-borne plant pathogens were reported previously by many investigators (Ragab et al. 1999; El-Mougy 2001).

Soil solarization proved to be an efficiency means for controlling soil-borne pathogens. Several investigators reported the efficacy of soil solarization in reducing the incidence and severity of plant diseases caused by soilborne pathogens (Martyn \& Hartz 1986; Greenberger et al. 1987; Abdel-Kader \& Ashour 1994). Soil solarization during summer months increases soil temperatures to levels lethal to many soilborne plant pathogens (Arya 2007). In present study, results indicate that solarization was more effective in reducing the bean root rot disease than un- solarized soil. The inability of organisms to tolerate high temperatures is related to an upper limit in the degree of fluidity of membranes, beyond which breakdown of membrane function may be associated with membrane instability (Sundarum 1986). Additional causes for the thermal decline of microorganisms at high temperatures involve the sustained inactivation of respiratory enzymes (Brock 1978; Sundarum 1986). These are direct affects of high soil temperatures and account for a major share of the reduction in populations of soil-borne micro-organisms and weed seeds. On the other hand, some effects of soil solarization are indirect. For example, cells of plant pathogens weakened by heat stress are more vulnerable by several orders of magnitude to soil fumigants, to antagonistic micro-organisms which are more able to tolerate high soil temperatures, and to changes in the gas environment which may develop during soil solarization. This increase in temperatures at different soil depths could affect the population density of soil microflora including the plant pathogens. This fact was previously recorded by Katan et al. (1976) and Katan (1980), who demonstrated that the population of soilborne fungi, i.e. Fusarium oxysporum, Rhizoctonia solani and Sclerotium rolfsii, reduced by 62 to $100 \%$ at 5 to $25 \mathrm{~cm}$ depths in solarized soil. They added that the maximal temperatures in mulched soils reached 52,49 and $42^{\circ} \mathrm{C}$ at 5,15 and $25 \mathrm{~cm}$ soil depths, respectively. Pullman et al. (1981) presented a detailed study on thermal death of four soil-borne plant pathogens as affected by time and temperature of the treatment. They reported that $R$. solani was found to be killed at $50^{\circ} \mathrm{C}$ in only $10 \mathrm{~min}$. as exposure time. In the present study, the recorded soil temperature measured at 10, 20 and $30 \mathrm{~cm}$ of soil depths in mulched soil reached average of 56.5, 51.5 and $46.5^{\circ} \mathrm{C}$ during eight weeks of mulching period. Many researches had been done using the biological control as viable and reliable practice against many soil-borne pathogens in modern agriculture (Adams, 1990; Campbell, 1990). Moreover, the effect of soil solarization combined with the antagonistic microbes or fungicides application to control soilborne pathogens was studied by many workers. Also, Greenberger et al. (1984) studied the efficacy of biological control in solarized soil. They suggested that a suppressiveness phenomenon was developed in solarized soil in addition to introduced the antagonists Bacillus spp. which reflected on reduction in the incidence of bean root rot and tomato wilt caused by Sclerotium rolfsii and $F$. oxysporum f. sp. lycopersici, respectively. Furthermore, Yucel and Cali (1997) applied Trichoderma harzianum in solarized soil to control tomato wilt caused by $F$. oxysporum f. sp. lycopersici and reported that disease incidence was significantly reduced by this treatment. The phenomenon of antagonism has received much attention during the last few years. Many successful attempts 
Table 4 Bean root rot disease incidence in response to applied treatments different bio-agents and composts in solarized or un-solarized soil during two successive growing seasons

\begin{tabular}{|c|c|c|c|c|c|c|c|c|}
\hline \multirow{4}{*}{ Soil application } & \multicolumn{8}{|c|}{ Bean root rot incidence $\%$} \\
\hline & \multicolumn{4}{|c|}{ Winter growing season, 2011} & \multicolumn{4}{|c|}{$\begin{array}{c}\text { Early summer growing season, } \\
2012\end{array}$} \\
\hline & \multicolumn{2}{|c|}{$\begin{array}{l}\text { Solarized } \\
\text { soil }\end{array}$} & \multicolumn{2}{|c|}{$\begin{array}{l}\text { Un- solarized } \\
\text { soil }\end{array}$} & \multicolumn{2}{|c|}{$\begin{array}{l}\text { Solarized } \\
\text { soil }\end{array}$} & \multicolumn{2}{|c|}{ Un- solarized soil } \\
\hline & Pre- ${ }^{1}$ & Post- $^{2}$ & Pre- & Post- & Pre- & Post- & Pre- & Post- \\
\hline \multicolumn{9}{|c|}{ Single treatment } \\
\hline Compost $\mathrm{p}$ & 8.2 & 12.2 & 11.3 & 22.2 & 9.3 & 13.4 & 12.6 & 24.2 \\
\hline Compost A & 7.1 & 11.5 & 10.5 & 16.2 & 8.6 & 12.3 & 11.7 & 17.3 \\
\hline T. harzianum & 7.3 & 12.3 & 12.2 & 14.3 & 8.3 & 12.8 & 13.6 & 15.7 \\
\hline P. fluorescens & 7.5 & 13.7 & 11.5 & 15.5 & 8.5 & 14.3 & 12.8 & 16.8 \\
\hline \multicolumn{9}{|c|}{ Combined treatment } \\
\hline Compost $\mathrm{P}+T$. harzianum & 5.2 & 8.4 & 8.5 & 11.4 & 7.2 & 10.4 & 9.6 & 13.3 \\
\hline Compost $\mathrm{P}+P$. fluorescens & 5.2 & 9.2 & 8.5 & 12.2 & 6.8 & 10.3 & 10.2 & 14.4 \\
\hline Compost $\mathrm{A}+T$. harzianum & 4.3 & 4.5 & 6.6 & 8.6 & 5.4 & 6.3 & 7.2 & 10.2 \\
\hline Compost $\mathrm{A}+P$. fluorescens & 4.4 & 5.3 & 6.5 & 8.2 & 5.9 & 7.8 & 7.6 & 10.3 \\
\hline Fungicide (Rizolex-T) & 5.3 & 4.5 & 6.3 & 8.4 & 6.8 & 6.7 & 8.2 & 10.7 \\
\hline Control & 15.0 & 34.4 & 21.6 & 43.0 & 17.7 & 36.6 & 23.6 & 44.4 \\
\hline \multicolumn{9}{|l|}{ LSD at 0.05 for } \\
\hline At pre-emergence: Mulched soil (M) & \multicolumn{4}{|c|}{4.36} & \multicolumn{4}{|c|}{3.84} \\
\hline Treatment $(\mathrm{T})$ & \multicolumn{4}{|c|}{1.12} & \multicolumn{4}{|c|}{1.08} \\
\hline Between $(\mathrm{M}) \times((\mathrm{T})$ & \multicolumn{4}{|c|}{2.87} & \multicolumn{4}{|c|}{2.64} \\
\hline \multicolumn{9}{|l|}{ At post-emergence : Mulched soil (M) } \\
\hline Treatment $(\mathrm{T})$ & \multicolumn{4}{|c|}{14.36} & \multicolumn{4}{|c|}{11.14} \\
\hline Between $(\mathrm{M}) \mathrm{x}((\mathrm{T})$ & \multicolumn{4}{|c|}{2.14} & \multicolumn{4}{|c|}{1.81} \\
\hline & \multicolumn{4}{|c|}{3.24} & \multicolumn{4}{|c|}{3.36} \\
\hline
\end{tabular}

1: Root rot incidence at pre-emergence growth stage

2: Root rot incidence at post-emergence growth stage

for controlling disease producing plant pathogens were reported. Ranguchander, et al. (1997) determined the efficacy of seed treatment and row application of $T$. harzianum and $T$. viride on control of dry root rot of mungbean caused by $M$. phaseolina. Sclerotial number of the pathogen and root rot incidence were greatly reduced with seed treatment of the antagonists, as compared to row application. These records confirmed the obtained results in the present study. Whereas all applied treatments in solarized soil showed high efficacy for controlling bean root rot disease incidence. The most effective treatments were $T$. harzianum or P. fluorescens combined with the compost A or P in solarized soil which reduced the root rot disease incidence at both pre-, and post-emergence growth stages. Furthermore, during heat treatments of soil, changes occur in the structure of soil, in soluble mineral substances available for plant and microbial growth, and in the populations of soilborne micro-organisms (Chen and Katan 1980; Stapleton and De Vay, 1986; Stapleton, et al. 1985). These changes could be on the side of vegetative plant growth and produced yield as a result. In this concern, reduction in disease incidence and increasing obtained yield due to soil solarization alone or combined with other treatments were reported by many investigators (Katan 1980; Osman et al. 1986). Abdel-Kader and Ashour (1994) reported that fungicides combined with soil solarization were more effective in reducing percentage of lupin wilt and increased yield in naturally infested soil with the causal fungus than each treatment alone. Moreover, biological treatment in solarized soil gave good effect, as control measure, for soilborne plant pathogens beside beneficial side effects on plant growth and obtained yield (Abdel-Kader 1997; AbdelKader \& Ashour 1999). They reported an 
Table 5 Bean yield at different bio-agents and composts in solarized or un-solarized soil during two successive growing seasons

\begin{tabular}{|c|c|c|c|c|c|c|c|c|}
\hline \multirow{4}{*}{ Soil application } & \multicolumn{8}{|c|}{ Bean yield $\mathrm{kg} /$ feddan $\left(4200 \mathrm{~m}^{2}\right)$} \\
\hline & \multicolumn{4}{|c|}{ Winter growing season, 2011} & \multicolumn{4}{|c|}{$\begin{array}{c}\text { Early summer growing season, } \\
2012\end{array}$} \\
\hline & \multicolumn{2}{|c|}{$\begin{array}{c}\text { Solarized } \\
\text { soil }\end{array}$} & \multicolumn{2}{|c|}{ Un-solarized soil } & \multicolumn{2}{|c|}{$\begin{array}{c}\text { Solarized } \\
\text { soil }\end{array}$} & \multicolumn{2}{|c|}{ Un-solarized soil } \\
\hline & yield & $\begin{array}{c}\text { Increase } \\
\% \\
\end{array}$ & yield & $\begin{array}{c}\text { Increase } \\
\% \\
\end{array}$ & yield & $\begin{array}{c}\text { Increase } \\
\% \\
\end{array}$ & yield & $\begin{array}{c}\text { Increase } \\
\% \\
\end{array}$ \\
\hline \multicolumn{9}{|c|}{ Single treatment } \\
\hline Compost $\mathrm{p}$ & 1300 & 30.0 & 1050 & 31.2 & 1238 & 25.0 & 988 & 25.8 \\
\hline Compost A & 1345 & 34.5 & 1100 & 37.5 & 1312 & 32.5 & 1058 & 34.7 \\
\hline T. harzianum & 1250 & 25.0 & 1070 & 33.7 & 1189 & 20.1 & 1034 & 31.7 \\
\hline P. fluorescens & 1200 & 20.0 & 1000 & 25.0 & 1175 & 18.6 & 975 & 24.2 \\
\hline \multicolumn{9}{|c|}{ Combined treatment } \\
\hline Compost $\mathrm{P}+T$. harzianum & 1450 & 45.0 & 1165 & 45.6 & 1410 & 42.4 & 1127 & 43.5 \\
\hline $\begin{array}{l}\text { Compost } \mathrm{P}+P . \text { fluorescens } \\
\text { Compost } \mathrm{A}+T \text {. harzianum }\end{array}$ & 1460 & $\begin{array}{l}46.0 \\
66.0\end{array}$ & $\begin{array}{l}1120 \\
1310\end{array}$ & 40.0 & 1434 & 44.8 & 1095 & $\begin{array}{l}39.7 \\
64.0\end{array}$ \\
\hline $\begin{array}{l}\text { Compost } \mathrm{A}+T . \text { harzianum } \\
\text { Compost } \mathrm{A}+P . \text { fluorescens }\end{array}$ & 1600 & 60.0 & $\begin{array}{l}1510 \\
1275\end{array}$ & $\begin{array}{l}0.1 \\
59.3\end{array}$ & $\begin{array}{l}1020 \\
1548\end{array}$ & 56.3 & $\begin{array}{l}1200 \\
1238\end{array}$ & 57.7 \\
\hline Fungicide (Rizolex-T) & 1400 & 40.0 & 1150 & 43.7 & 1376 & 38.9 & 1094 & 39.3 \\
\hline Control & 1000 & -- & 800 & -- & 990 & -- & 785 & -- \\
\hline \multicolumn{9}{|l|}{ LSD at 0.05 for } \\
\hline Mulched soil (M) & \multicolumn{4}{|c|}{34.12} & \multicolumn{4}{|c|}{31.24} \\
\hline Treatment $(\mathrm{T})$ & \multirow{2}{*}{\multicolumn{4}{|c|}{$\begin{array}{l}18.32 \\
26.42\end{array}$}} & \multirow{2}{*}{\multicolumn{4}{|c|}{14.62}} \\
\hline Between $(\mathrm{M}) \times((\mathrm{T})$ & & & & & & & & \\
\hline
\end{tabular}

announced reduction in root rot incidence of bean and cowpea, caused by the pathogens $R$. solani and $F$. solani, was achieved using the antagonists $T$. harzianum as soil drench either in solarized or un-solarized soil. Similar results were also reported by Ragab et al. (1999) and El-Mougy (2001) against root rot disease of pea and bean plants.

\section{Conclusion}

The obtained results in the present study indicate that, solarization and biological control are considered as non-chemical control methods which have advantage and limitation. Therefore, application of biological agents as soil application or seed dressing, in either solarized or un-solarized soil, could be used as an effective and unhazard applicable technique for controlling soil-borne plant pathogens in addition to avoid environmental pollution due to decrease the usage of chemical fungicides. The integration of solarization with biological and cultural methods may improve the control of soil-borne pathogens, especially these caused root rot diseases. The technique evaluated in the present study could be recommended in light of the results obtained. The use of combined treatment of compost and bio-agents could be considered a safe, cheap and easily applied bio-control method to be used against soil-borne plant pathogens, particularly for organic farmers, for avoiding environmental pollution.

\section{Acknowledgments}

This work was supported financially by the National Research Centre Fund (NRC), Egypt, Grant No. 9050204.

\section{References}

Abdel-Kader MM. 1997 - Field application of Trichoderma harzianum as biocide for control bean root rot disease. Egypt. J. Phytopathol. 25, 19-25.

Abdel-Kader MM, Ashour AMA. 1994 Chemical control of lupin wilt disease in solarized soil. Proc. of $7^{\text {th }}$ Congr. Phytopathol. Egypt., 363-367.

Abd-El-Karem F, Abdallah MA, El-Gamal NG, 
El-Mougy NS. 2004 - Integrated control of Lupin root rot disease in solarized soil under greenhouse and field condition Egypt. J. Phytopathol. 32, 49-63.

Adams PB 1990 - The potential of mycoparasites for biological control of plant disease. Ann. Rev. Phytopathol. 28, $59-72$.

Arya A. 2007 - Soil solarization to control wilt disease of pigeon pea. Seed borne diseases. 20, 265-270.

Baker KF, Cook RJ. 1974 - Biological Control of Plant Pathogens. Freeman, San Francisco. 433 pp.

Barnett HL, Hunter BB. 1972 - Illustrated Genera of Imperfect Fungi. Burgess Publishing Co. Minneapolis, Minnesota, $241 \mathrm{pp}$.

Borrero C, Trillas MI, Ordova's J, Tello J, Avile's M. 2004 - Predictive factors for the suppression of Fusarium wilt of tomato in plant growth media. Phytopathology 94, 1094-1101

Bremner JM, Mulvaney CS. 1982 - Nitrogen Total. In: Methods of Soil Analysis. 2nd ed., Part 2 ed., A. L. Page, R. H. Miller, and D. R. Keeney ( eds.). Agronomy Monograph No. 9. Madison, WI: American Society of Agronomy, pp: 295-324.

Brock TD, $1978 \quad-\quad$ Thermophylic Microorganisms and Life at High Temperatures. Springer-Verlag, New York., 465 pp.

Campbell R, 1990 - Biological control of soilborne diseases, some present problems and different approaches. Crop Protection 13, 4-13.

Celar F. 2000- Cucurbit diseases. Sodobno Kmetijstvo 33:162-165. [c.f. Review of Plant Pathology 79, 1037.

Cenis JL. 1987 - Double plastic sheet for improving soil solarization efficiency. In: Proc.7th Congress of the Mediterranean Phytopathological Union (Spain). p. 73.

Chen Y, Katan J. 1980 - Effect of solar heating of soils by transparent polyethylene mulching on their chemical properties. Soil Sci. 130, 271-277.
Cotxarrera L, Trillas-Gay MI, Steinberg C, Alabouvette C. 2002 - Use of sewage sludge compost and Trichoderma asperellum isolates to suppress Fusarium wilt of tomato. Soil Biol. Biochem. 34, 467-476

Culman SW, Duxbury JM, Lauren JG, Thies JE. 2006 - Microbial community response to soil solarization in Nepal's rice and wheat cropping system. Soil Biol.Biochem. 38, 3359-3371.

Dawson JR, Johnson RA, Adams P, Last FT. 1965 - Influence of steam/air mixtures, when used for heating soil, on biological and chemical properties that affect seedling growth. Ann. Appl. Biol. 56:24351.

El-Mougy NS. 2001 - Field application of certain biological and chemical approaches on controlling bean wilt disease. Egypt. J. Phytopathol. 29, 6978.

Farrag ESH, Fotouh YO. 2010 - Solarization as a method for producing fungal-free container soil and controlling wilt and root-rot diseases on cucumber plants under greenhouse conditions. Archives of Phytopathology and Plant Protection 43, $519-526$

Ferreira JHS, Matthee FN, Thomas AC. 1991Biological control of Eutypa lata on Grapevine by an antagonistic strain of Bacillus subtilis. Phytopathology 81, 283-287.

Filion MM, Arnaud ST, Jabaji-Hare SH. 2003 - Quantification of Fusarium solani f. sp. phaseoli in Mycorrhizal Bean Plants and Surrounding Mycorrhizosphere Soil Using Real-Time Polymerase Chain Reaction and Direct Isolations on Selective Media. Phytopathology 93, 229 $-235$.

Gilman JC. 1957 - “A Manual of Soil Fungi”. The Iowa State College Press Ames. Iowa, $450 \mathrm{pp}$.

Greenberger A, Vogev A, Katan J. 1984 Biological control in solarized soils. Proc. of $6^{\text {th }}$ Congr. Phytopathol. Mediterr. Un. Egypt pp. 112-114. 
Greenberger A, Vogev A, Katan J. 1987 Induced suppressiveness in solarized soils. Phytopathology 77, 1663-1667.

Harveson RM, Smith J, Stroup WW. 2005 Improving Root Health and Yield of Dry Beans in the Nebraska Panhandle with a New Technique for Reducing Soil Compaction Plant Dis. 89, 279-184.

Hoitink HAJ, Fahy PC. 1986 - Basis for the control of soilborne plant pathogens with composts. Ann. Rev. Phytopathol. 24, 93-114.

Hoitink HAJ, Boehm MJ. 1999 - Biocontrol within the context of soil microbial communities: a substrate-dependent phenomenon. Ann. Rev. Phytopathol. 37, 427-446

Hoitink HAJ, Schmitthener AF, Herr LJ. 1975 - Composted bark for control of root rot in ornamentals. Ohio Rep. 60, 25-26.

Hoitink HAJ, Madden LV, Dorrance AE. 2006 - Systemic Resistance Induced by Trichoderma spp.: Interactions Between the Host, the Pathogen, the Biocontrol Agent, and Soil Organic Matter Quality. Phytopathology 96, 186-189.

Horiuchi S. 1984 - Soil solarization for suppressing soilborne diseases in Japan. p. 11-23. In: The Ecology and Treatment of Soilborne Diseases in Asia. Food and Fertilizer Technology Center Tech. Bull. 78. Taiwan,R.O.C.

Horst, L.E., Locke, J., Krause, C.R., 2005 Suppression of Botrytis Blight of Begonia by Trichoderma hamatum 382 in Peat and Compost-Amended Potting Mixes. Plant Dis. 89, 1195-1200.

Katan J. 1980- Solar pasteurization of soils for disease control: status and prospects. $\mathrm{Pl}$. Dis. Reptr. 64, 450-454

Katan J, Greenberger A, Alon H, Grinstein A. 1976 - Solar heating by polyethylene mulching for the control of diseases caused by soilborne pathogens. Phytopathology 66, 683-688.

Katan J, Grinstein A, Greenberger A, Yarden O, DeVay JE. 1987 - The first decade (1976-1986) of soil solarization (solar heating): a chronological bibliography. Phytoparasitica 15:229-255.
Martyn RD, Hartz TK. 1986 - Soil solarization for control of Fusarium wilt of watermelon. Phytopathology 76, 402. (Abstr.).

Mclean EO. 1982 - Soil pH and lime requirement. In: Methods of Soil Analysis. 2nd ed., Part 2 ed., A. L. Page, R. H. Miller, and D. R. Keeney ( eds.). Agronomy Monograph No. 9. Madison, WI: American Society of Agronomy, pp: 595-624.

MSTAT-C. 1988 - MSTAT-C, a microcomputer program for the design, arrangement and analysis of agronomic research. Michigan State University, East Lansing.

Nelson DW, Sommers LE. 1982 - Total carbon, organic carbon and organic matter. In: Methods of soil analysis. 2nd ed., Part 2 ed., A. L. Page, R. H. Miller, and D. R. Keeney (eds.). Agronomy Monograph No. 9. Madison, WI: American Society of Agronomy, pp 539579.

Odu CT I, Babalola O, Udo EJ, Ogunkunle AO, Bakare TA, Adeoye GO. 1986 Laboratory manual for agronomic studies in soli, plant and microbiology. $1^{\text {st }} \mathrm{Ed}$. Department of Agronomy, University of Ibadan, Ibadan, Nigeria, 83 p.

Olsen SR, Sommers LE. 1982 - Phosphorus. In: Methods of Soil Analysis. 2nd ed., Part 2 ed., A. L. Page, R. H. Miller, and D. R. Keeney (eds.). Agronomy Monograph No. 9. Madison, WI: American Society of Agronomy, pp: 403-430.

Osman AR, Fahim MM, Sahab AS, AbdelKader MM. 1986- Soil solarization for the control of lupin wilt. Egypt. J. Phytopathol. 18, 75-88.

Page AL, Miller RH, Keeney DR. 1982Methods of Soil Analysis. Chemical and Microbiological Properties, $2^{\text {nd }}$ Ed. Madison, Wisconsin, USA., pp. 257.

Primo PD, Cartia G. 2001- Solarization and biofumigation to control Fusarium oxysporum f.sp. melonis. Informatory Agrario. 57, 55-58.

Pullman GS, DeVay JE, Garber RH. 1981 - 
Soil solarization and thermal death: A logarithmic relationship between time and temperature for four soilborne plant pathogens. Phytopathology 71, 959-964.

Punja ZK, Utkhede RS. 2004 - Biological control of fungal diseases on vegetable crops with fungi and yeasts. In: Fungal Biotechnology in Agricultural, Food, and Environmental Applications (ed. D.K. Arora), New York Basel, 157-171.

Ragab MM, Aly MDH, Ragab MMM, El-

Mougy NS. 1999 - Effect of fungicides, biocides and bioagents on controlling of pea root rot disease. Egypt. J. Phytopathol. 27, 65-81.

Ranguchander T, Rajappan K, Samiappan RG. 1997 - Evaluation methods of application of biological agent in control of mungbean root rot. Indian Phytopathol. 50, 229-234.

Rose S, Parker M, Punja ZK. 2003 - Efficacy of Biological and Chemical Treatments for Control of Fusarium Root and Stem Rot on Greenhouse Cucumber. Plant Dis. 87, 1462-1470.

Snedccor GW, Cochran W. 1980 - Statistical Methods. $7^{\text {th }}$ Edn, Jowa State Univ., Press, Jowa, USA.

Sharon E, Bar-Eyal M, Chet I, Herrera A, Kleifeld O, Spiegel Y. 2001 - Biological Control of the Root-Knot Nematode Meloidogyne javanica by Trichoderma harzianum. Phytopathology 91, 687-693.

Shoresh M, Yedidia I, Chet I. 2005Involvement of Jasmonic Acid/Ethylene Signaling Pathway in the Systemic Resistance Induced in Cucumber by Trichoderma asperellum. Phytopathology 95, 76-84.

Sivan A. 1987 - Biological control of Fusarium crown rot of tomato by Trichoderma harzianum under field conditions. Plant Dis. 71, 587-592.

Sivan A, Chet I. 1992 - Microbial control of plant disease. In: Mitchell $\mathrm{R}$ (ed) Environmental microbiology. Wiley, New York, pp 335-354
Stapleton JJ, DeVay JE. 1982 - Effect of soil solarization on populations of selected soilborne microorganisms and growth of deciduous fruit tree seedlings. Phytopathol. 72:323-326.

Stapleton JJ, DeVay JE. 1986 - Soil solarization: a non-chemical approach for management of plant pathogens and pests. Crop Protection 5, 190-198

Stapleton JJ, Quick J, DeVay JE. 1985- Soil solarization: effect on soil properties, crop fertilizers and plant growth. Soil Biol. Biochem. 17, 369-373.

Sundarum TK. 1986 - Physiology and growth of thermophylic bacteria. p. 5. In: Thermophiles: General. Molecular, and Applied: Microbiology. T. D. Brock, ed. John Wiley and Sons, New York. 316 pp.

Thomas GW. 1982 - Exchangeable cations. In: Methods of Soil Analysis. 2nd ed., Part 2 ed., A. L. Page, R. H. Miller, and D. R. Keeney (eds.). Agronomy Monograph No. 9. Madison, WI: American Society of Agronomy, pp: 159-165.

Trillas MI, Casanova E, Corxarrera L, Ordovas J, Borrero C, Aviles M. 2006 - Composts from agricultural waste and the Trichoderma asperellum strain T-34 suppress Rhizoctonia solani in cucumber seedlings. Biol Control 39, 32-38.

Wen K, Seguin P, Arnaud MS, Jabaji-Hare S. 2005- Real-Time Quantitative RT-PCR of Defense-Associated Gene Transcripts of Rhizoctonia solani-Infected Bean Seedlings in Response to Inoculation with a Nonpathogenic Binucleate Rhizoctonia Isolate. Phytopathology 95, 345-353.

Yucel S, Cali S. 1997 - Studies on the effect of soil solarization combined with fumigant and antagonists in greenhouse to control soilborne pathogens in the East Mediterranean region of Turkey. $2^{\text {nd }}$ International Conf. on Soil Solarization and Integrated Management of Soilborne Pests. ICARDA, Aleppo, Syria, Abstracts Book, No. 43. 